Criticism and deconstruction-despite their very different aims - are founded not on scientific theory but on the fact that a sequence of words divorced from a determinate context-actual or fictive or both-has an infinite number of possible meanings, including selfcanceling ones. While theorists of deconstruction sometimes claim certain linguistic theories as its foundation, in doing so they simply repeat the gesture of previous literary sciences. Speaking of structuralism, Fredric Jameson writes: "Thus a method which began by seeing myths or artworks as language systems or codes in their own right ends up passing over into the view that the very subject matter of such works or myths is the emergence of Language or of Communication, ends up interpreting the work as a statement about language" ("Metacommentary," PMLA 86 [1971]: 15). Deconstruction's "allegory of reading" is not about the emergence of communication but about its deep "impossibility." Deconstruction is the most influential form of allegoresis today, and allegoresis has been the most potent form of interpretation since, well, since interpretation. It is, I would argue, interpretation not only all the way down (and up) but backward and forward as well.

ROGER SEAMON

University of British Columbia

\section{The Fall(?) of the Old English Female Poetic Image}

To the Editor:

In "The Fall(?) of the Old English Female Poetic Image" (104 [1989]: 822-29), Pat Belanoff remarks (with a reference to H. Damico's book on Wealhtheow and the Valkyries), "The Old Icelandic cognates of Old English ides-dis (singular) and disir (plural) - are used by the Eddic poet(s) to designate powerful women" (824). Although the Eddic poets may indeed have played with various associations between the $O E$ and $O N$ words, it is nonetheless a philological fact that $\mathrm{OE}$ ides and $\mathrm{OHG}$ ites are not cognate with ON dis [ir] (see G. H. TurvillePetre, Myth and Religion in the North, ch. 11, and J. de Vries, Altnordisches etymologisches Wörterbuch, s.v. dis). One cannot therefore conclude, as Belanoff does, that "these correspondences in descriptive language demonstrate that the generalized portrait of women in Old English literature lies deep in Germanic tradition" (824). The connection if any between the $\mathrm{ON}$ disir and the $\mathrm{OE}$ idese is restrictively medieval and purely poetic, not cultural and historically longstanding from barbarian days.

Another misconception of Belanoff's about the Ger- manic woman lies in her reading of Tacitus's characterization of female shamanism among the primitive Germans (Germania, ch. 8, as qtd. in Belanoff 823). From the shamanistic trait "providum" or "clairvoyant," no one, I believe, would suppose that Tacitus was paying a compliment to the intelligence of Germanic womankind. That would be as if, having listened to the prophesies of the female seer in the Old Icelandic Völuspá, someone in her audience were struck by her intelligence in foreseeing the end of the world. The reason that the primitive Germans attended to the counsels and sayings of their women (as Tacitus reports) was presumably that the women's utterances were regarded as inspired rather than as especially "intelligent" (see the Much-Kienast commentary on Germania, ch. 8). But from the Germania, Grimm's Teutonic Mythology, and the stock of $O E$ poetic formulas for female adornment Belanoff has formed the idiosyncratic opinion that "[t]hese [Germanic] women are both intelligent and shining" (823) and appear so in ON and OE poetry. Quite apart from the confusion of prophetic faculty with intelligence in this opinion, there also seems to be no suggestion in it of the function or role of women in heroic society among the Germanic peoples (e.g., the domestic role of Wealhtheow in Beowulf $611 \mathrm{ff}$.). I do not see how Belanoff's static and overintellectualized image of Germanic women can possibly represent the pagan heroines of the older northern literature before their Christian eclipse.

FREDERIC AMORY

University of San Francisco

\section{Reply:}

Amory rightly directs our attention to the murky and discordant statements about connections between $O N$ dis and $\mathrm{OE}$ ides. I suspect the discussion is not yet over. For example, J. de Vries, in a later publication than that cited by Amory, states no absolute conclusion; rather, after a discussion of ides, de Vries comments that its connection to disir is umstritten 'disputed' and for that reason he can support the connection only with difficulty (Altgermanische Religionsgeschichte, 3rd ed., Berlin: Gruyter, 1970, 321-22).

But connections do exist. The most telling evidence in the poetry is ides Scyldinga (Beowulf 1168b) of Wealhtheow and dis Skjoldunga of Brynhild in Brot af Sigurd viðu (14) and of Sigrun in Helgakviða Hundingsbana II (51). E. O. G. Turville-Petre moves beyond the etymological considerations referred to by Amory: "Even if not related, the words ides and dis are sufficiently alike for the poetical usage of the first to influence that of 